\title{
THE EFFECT OF HABITUALLY HIGH IRON INTAKE ON CERTAIN BLOOD VALUES IN PREGNANT BANTU WOMEN
}

\author{
By TH. GERRITSEN AND A. R. P. WALKER
}

\author{
(From the Human Biochemistry Unit, South African Institute for Medical Research, \\ Johannnesburg, and South African Council for Scientific and Industrial Research, \\ Johannesburg, South Africa)
}

(Submitted for publication April 28, 1953; accepted September 18, 1953)

The influence of pregnancy on certain blood values (hemoglobin, hematocrit, serum iron, and total iron binding capacity) and their significance in the "anemia of pregnancy" have been widely investigated.

Combined evidence indicates that as pregnancy proceeds, a significant fall occurs in levels of hemoglobin and hematocrit, the explanation being that the increase in plasma volume exceeds the total increases in hemoglobin and red cells (1). In addition, evidence shows a significant rise to occur in total iron-binding capacity $(2-4)$. There is not the same unanimity, however, with serum iron findings. Laurell (2), Lundström (5) in Sweden, and Ventura and Klopper (4) in England, have reported a fall in this value, detectable at midterm. Yet, in America, neither Fay, Cartwright, and Wintrobe (6) nor Rath et al. (3) found a significant change in serum iron during pregnancy; the latter authors, therefore, alleged that the Swedish data indicated widespread iron deficiency in that country. Presumably, the same inference applies to the English series.

In South Africa, we have been greatly interested in the iron metabolism of the Bantu because: $(a)$ their iron intake is often unusually high, sometimes as much as $200 \mathrm{mg}$. per diem, derived not only from the element present in their customary diet, but from adventitious iron taken up from iron utensils during the preparation of food $(7) ;(b)$ abnormally high serum iron values are occasionally encountered in adults (8); this investigation we have confirmed and considerably extended (9); (c) hypochromic anemia is extremely rare (10); (d) at necropsy, abnormal deposition of iron is frequently seen in the tissues of the adult Bantu (11-13). We thought, therefore, that it would be illuminating to determine the above blood values, particularly serum iron levels, in groups of pregnant and non-pregnant Bantu women whose everyday diet, although deficient in many respects according to accepted standards, is characterized by an habitually high iron content.

\section{MATERIALS AND METHODS}

The Bantu women, examined while attending health clinics, were partly from the Johannesburg urban area, though mainly from two rural native settlements near Pretoria. Subjects were thus dwelling 4,000 to 5,000 feet above sea level. This fact must be taken into account, bearing in mind that hemoglobin concentration increases with altitude (14). Obviously, it would have been desirable to have followed a series of subjects throughout the period of gestation. But attendance at clinics is most irregular ; moreover, many pregnant women do not attend until several months after conception.

The major source of calories for these people is maize, which is taken largely in the forms of cooked and sour porridges. This cereal is also used, with "kaffircorn" (sorghum), in the making of kaffir beer. These foodstuffs are usually prepared in the ubiquitous iron kaffir pots, though occasionally in paraffin cans. Several samples of foodstuffs were obtained from patients. The iron contents were determined by the thioglycollic acid method (15). Results are given in Table I.

Blood samples were taken by venipuncture between 9 a.m. and 10:30 a.m., the usual precautions being taken to prevent iron contamination. Determinations of hemoglobin, serum iron, and iron binding capacity were carried out in duplicate. Hemoglobin values were determined by the oxyhemoglobin method, using a HilgerSpekker absorptiometer (Ilford filter 602), calibrated against total iron determinations. For hematocrit, Wintrobe tubes were used, centrifuging for one hour at 3,000 r.p.m. Serum iron was determined by the thioglycollic acid method, and iron binding capacity according to the method of Rath and Finch (16). The total iron binding capacity was calculated by adding the serum iron value to the iron binding capacity.

Since Rath et al. (3) have shown that the main increase in iron requirement during pregnancy occurs towards the end of the second trimester, and since the Swedish $(2,5)$ and English (4) workers have reported a fall in serum iron at about mid-term, we divided our subjects into two groups, one from 4 to 22 weeks, and the other from 26 to 40 weeks duration. Results are given in Table II 
TH. GERRITSEN AND A. R. P. WALKER

TABLE I

Iron content of prepared foodstuffs consumed by our subjects

\begin{tabular}{lccc}
\hline \hline & Cooked porridge & Sour porridge & Kaffir beer \\
\hline $\begin{array}{l}\text { No. of samples } \\
\begin{array}{c}\text { Iron content : mean } \\
\text { range }\end{array}\end{array}$ & 20 & 18 & 12 \\
\hline
\end{tabular}

N.B. South African maize contains 0.2 to 18.0 , average $3.4 \mathrm{mg}$. Fe per $100 \mathrm{Gm}$. dry weight (17).

\section{DISCUSSION}

Dietary surveys by Smit (18) reveal that the quantity of maize consumed daily by the urban Bantu ranges from 6 to $21 \mathrm{oz}$. (170 to $590 \mathrm{Gm}$.) per head; that of wheat is from 5 to $15 \mathrm{oz}$. (140 to $420 \mathrm{Gm}$.). Information obtained by our dietitian, Miss J. L. Seward, on visiting homes of patients, together with information given by the patients themselves, suggest that: $(a)$ the consumption of maize per diem by our subjects averaged about $1 \mathrm{lb}$. (450 Gm.) ; (b) about four-fifths of the maize bought is consumed as cooked porridge and the remainder as sour porridge; and (c) our subjects consumed an average of about $100 \mathrm{ml}$. kaffir beer per diem.

Using data given in Table I, the iron contribution by $0.8 \mathrm{lb}$. (360 Gm.) cooked maize ranged from 17 to $70 \mathrm{mg}$.; that from $0.2 \mathrm{lb}$. (90 Gm.) sour porridge, 5 to $120 \mathrm{mg}$.; that contained in $100 \mathrm{ml}$. kaffir beer, from 1.1 to $12.0 \mathrm{mg}$. Hence, the total iron ingested from these sources ranged from 23 to $202 \mathrm{mg}$., the mean value being $171 \mathrm{mg}$. per diem. Of course, additional amounts of iron are supplied by other components of the diet, e.g., bread, legumes, vegetables and meat. This unusually high iron intake may be compared with the allowance currently recommended for pregnant women, namely, $15 \mathrm{mg}$. iron per diem (1)-a level not always reached by such subjects in the United States or Britain $(19,20)$. While we do not wish to attach undue importance to our figures, it must be stressed that these people are habituated to an iron intake far higher than that of Europeans, although the diet is deficient in several respects according to accepted standards.

Table II indicates that during pregnancy there is a significant rise in total iron binding capacity, but there is no significant fall in hemoglobin, hematocrit, nor serum iron.

As mentioned in the introduction, during pregnancy it is usual for hemoglobin concentration and hematocrit value to fall to a variable extent. These reductions, however, may be regarded as "physiological" and not essentially as indicative of iron deficiency. Hypochromic anemia from the latter cause is considered to be present only when the reduction in hemoglobin concentration reaches a certain level, normally placed at $11 \mathrm{Gm}$. per 100 $\mathrm{ml}$. (21). The constancy of hemoglobin concentration and hematocrit levels during the pregnancy of the Bantu subjects is therefore most remarkable. One possibility is that there has been no increase in

TABLE II

Blood values in non-pregnant and pregnant Bantu women (18 to 40 years)

\begin{tabular}{|c|c|c|c|c|}
\hline $\begin{array}{c}\text { Period of } \\
\text { pregnancy }\end{array}$ & Hemoglobin & Hematocrit & $\begin{array}{l}\text { Serum iron } \\
(\gamma / 100 \mathrm{ml} \text {. } \\
\text { serum })\end{array}$ & $\begin{array}{c}\text { Total } \\
\text { iron-binding } \\
\text { capacity } \\
(\gamma / 100 \mathrm{ml} \text {. } \\
\text { serum })\end{array}$ \\
\hline $\begin{array}{l}\text { Non-pregnant } \\
(48)^{*}\end{array}$ & $\begin{array}{c}\text { Gm. \% } \\
13.9 \pm 0.9 \\
(12.3-16.0)\end{array}$ & $\begin{array}{c}\% \\
42.9 \pm 2.9 \\
(38-49)\end{array}$ & $\begin{array}{r}119 \pm 32 \\
(65-195)\end{array}$ & $\begin{array}{r}323 \pm 45 \\
(225-445)\end{array}$ \\
\hline $\begin{array}{l}\text { 0-22 weeks } \\
(43)^{*}\end{array}$ & $\begin{array}{r}13.9 \pm 0.9 \\
(12.2-15.9)\end{array}$ & $\begin{array}{c}41.5 \pm 3.5 \\
(34-49)\end{array}$ & $\begin{array}{c}121 \pm 37 \\
(30-205)\end{array}$ & $\begin{array}{r}342 \pm 54 \\
(200-475)\end{array}$ \\
\hline $\begin{array}{c}26-40 \text { weeks } \\
(49)^{*}\end{array}$ & $\begin{array}{c}13.7 \pm 1.1 \\
(11.8-17.3)\end{array}$ & $\begin{array}{c}41.3 \pm 3.4 \\
(34-48)\end{array}$ & $\begin{array}{r}120 \pm 46 \\
(45-280)\end{array}$ & $\begin{array}{l}403 \pm 58 \\
(260-525)\end{array}$ \\
\hline
\end{tabular}

* Number of subjects. 
blood volume. This, however, is most unlikely, in view of the mass of published observations (at least among white pregnant women) to the contrary. A second and more likely possibility is that the increase in plasma volume as pregnancy progresses, is quantitatively paralleled by increases in total hemoglobin and total red cells. Whether this actually occurred must remain in doubt, since it was impracticable to carry out a series of determinations of blood volumes throughout pregnancy. Regarding this constancy of hemoglobin and hematocrit values, the following observations in the literature appear to be relevant to our subjects:

$a$. In the presence of a high iron intake, an otherwise inadequate diet does not prevent satisfactory hemoglobin production, even when chronic or acute hemorrhage occurs. Thus, in hypochromic anemia due to hookworm infestation, hemoglobin levels can be largely restored to normal limits by iron therapy alone, without either improvement in diet or removing the parasites from the intestinal tract $(22,23)$. Furthermore, in poorly nourished Chinese blood donors, it has been found that hypochromic anemia can be prevented by iron therapy alone, without improving the diet consumed (24).

$b$. In non-anemic subjects with hemoglobin values within normal limits, a high iron intake can stimulate increased hemoglobin production. This elevation, not invariably observed, is usually transient $(19,21,22,24)$.

c. In non-anemic pregnant women, it has been reported that a high intake can stimulate the production of hemoglobin and red cells, thus maintaining normal values throughout pregnancy (25, 26).

Turning now to our Bantu subjects-their diet is inadequate (low in animal protein, fat, certain vitamins and mineral salts). But during pregnancy, and for years previously, their intake of iron has been very high. Their reserves of the element are thus probably unusually large. The presence of excessive reserves is verified frequently at post mortem; for example, in the Johannesburg area, Higginson, Gerritwen, and Walker (13) have noted that 50 per cent of adult females reveal abnormal deposition of iron in the tissues, often to a marked degree. The explanation of unchanged blood values in pregnancy would, therefore, seem to be the unusually high iron intake of our subjects.

Our finding of no significant change in serum iron value during pregnancy agrees with the observations of the American workers $(3,6)$ and argues against the validity of the belief of Lundström (5) that a fall, inter alia, of serum iron in pregnancy, is "physiologic."

The rise we observed in total iron binding capacity is in harmony with other workers' findings $(2,4,5)$. As far as we are aware, no explanation has been advanced to account for the phenomenon. There are two factors which may be of relevance. Firstly, iron is transported apparently exclusively by a $\beta_{1}$ globulin component of serum protein (27): Secondly, reduction in the albumin-globulin ratio reported to occur in pregnancy $(28,29)$ suggests that the concentration of the particular iron binding globulin may be increased as gestation proceeds, although it forms only a small percentage of the total globulin fraction.

\section{SUMMARY}

The iron metabolism of the South African Bantu is marked by: (a) an habitually high iron intake; $(b)$ occasionally elevated serum iron values; $(c)$ extreme rarity of hypochromic anemia; and $(d)$ abnormal deposition of iron in tissues of adult Bantu examined at necropsy.

Certain blood values have been determined on pregnant Bantu women, consuming a diet characterized by its very high iron content though otherwise inadequate. On comparing data in the first and second halves of the pregnancy period, it has been found that there is no significant change in values for hemoglobin, hematocrit, or serum iron. The constancy of these values would seem to be due to the unusually high iron intake of these people.

\section{ACKNOWLEDGMENTS}

For facilitating our examination of the Bantu women, we are indebted to Drs. R. J. Smith and P. Hingle of the Union Department of Health, Pretoria; to Dr. M. Preiss of the Lady Selbourne Health Centre, Pretoria; also to Drs. S. Wayburne and D. W. P. Lavery, Baragwanath Non-European Hospital, Johannesburg. For assistance in carrying out some of the hemoglobin and hematocrit values, we are grateful to Dr. I. Bersohn, South African Institute for Medical Research, Johannesburg. 
This paper is published with the permission of the South African Council for Scientific and Industrial Research.

\section{REFERENCES}

1. Whitby, L. E. H., and Britton, C. J. C., Disorders of the Blood; Diagnosis, Pathology, Treatment, Technique, ed. 6, Philadelphia, Blakiston, 1950, p. 759.

2. Laurell, C. B., Studies on the transportation and metabolism of iron in the body, with special reference to the iron-binding component in human plasma. Acta physiol. Scandinav., supp. 46, 1947.

3. Rath, C. E., Caton, W., Reid, D. E., Finch, C. A, and Conroy, L., Hematological changes and iron metabolism of normal pregnancy. Surg., Gynec. \& Obst., 1950, 90, 320.

4. Ventura, S., and Klopper, A., Iron metabolism in pregnancy; the behaviour - of haemoglobin, serum iron, the iron-binding capacity of serum proteins, serum copper and free erythrocyte protoporphyrin in normal pregnancy. J. Obst. \& Gynaec. Brit. Emp., 1951, 58, 173.

5. Lundström, P., Studies on erythroid elements and serum iron in normal pregnancy. Acta Soc. Med. Upsal., 1950, 55, 1.

6. Fay, J., Cartwright, G. E., and Wintrobe, M. M., Studies on free erythrocyte protoporphyrin, serum iron, serum iron-binding capacity and plasma cepper during normal pregnancy. J. Clin. Invest., 1949, 28, 487.

7. Walker, A. R. P., and Arvidsson, U. B., Iron intake and haemochromatosis in the Bantu. Nature, 1950, 166, 438.

8. Squires, B. T., Serum iron in the Tswana (Bechuanaland). South African J. M. Sc., 1952, 17, 1.

9a. Gerritsen, Th., and Walker, A. R. P., Serum iron and iron-binding capacity in the South African Bantu. Nature, 1953, 171, 699.

9b. Gerritsen, Th., and Walker, A. R. P., Serum iron and iron-binding capacity in the Bantu. South African M. J., 1953, 27, 577.

10. Murray, J. F., Private communication, 1952.

11. Strachan, A. S., Haemosiderosis and haemochromatosis in South African natives, with a comment on the aetiology of haemochromatosis, M. D. Thesis, Glasgow, 1929.

12. Gillman, J., Mandelstam, J., and Gillman, T., A comparison of chemical and histological estimations of the iron and copper content of the livers of Africans in relation to the pathogenesis of cytosiderosis and cirrhosis (haemochromatosis). South African J. M. Sc., 1945, 10, 109.

13. Higginson, J., Gerritsen, Th., and Walker, A. R. P., Siderosis in the Bantu of Southern Africa. Am. J. Path., In press.

14. Wright, S. with the collaboration of Maizels, M., and Jepson, J. B., Applied Physiology, ed. 9, London, New York, Oxford University Press, 1952, p. 1190.
15. McCance, R. A., Widdowson, E. M., and Shackleton, L. R. B., The nutritive value of fruits, vegetables and nuts. Spec. Rep. Ser. Med. Res. Coun. London No. 213, 1936.

16. Rath, C. E., and Finch, C. A., Chemical, clinical, and immunological studies on the products of human plasma fractionation. XXXVIII. Serum iron transport. Measurement of iron-binding capacity of serum in men. J. Clin. Invest., 1949, 28, 79.

17. Crawford, D. C., Hamersma, P. J., and Marloth, B. W., The chemical composition of some South African cereals and their milling products. Pretoria. Union S. Africa Dept. of Agriculture \& Forestry. Science bull. No. 20, 1942.

18. Smit, R. J., A survey of wheat and maize consumption in Bantu urban areas (1949). South African M. J., 1950, 24, 258.

19. Widdowson, E. M., and McCance, R. A., Iron in human nutrition. J. Hyg., 1936, 36, 13.

20. Widdowson, E. M., and McCance, R. A., The absorption and excretion of iron before, during and after a period of very high intake. Biochem. J., 1937, 31, 2029.

21. Dubach, R., Callender, S. T. E., and Moore, C. V., Studies in iron transportation and metabolism; $\mathrm{ab}$ sorption of radioactive iron in patients with fever and with anaemias of varied etiology. Blood, 1948, $3,527$.

22. Hynes, M., Ishaq, M., and Verma, O. P., The effect of different diets and of iron medication on the nutritional anaemia of Indian army recruits. Indian $\mathrm{J}$. M. Research, 1946, 34, 273.

23. Cruz, W. O., and Pimenta de Mello, R., Prophylaxis of hookworm anemia-deficiency disease. Blood, 1948, $3,457$.

24. Snapper, I., Liu, S. H., Chung, H. L., and Yü, T. F., Anaemia from blood donation. A hematological and clinical study of 101 professional donors. Chinese M. J., 1939, 56, 403.

25. Lund, C. J., Studies on the iron-deficiency anaemia of pregnancy, including plasma volume, total hemoglobin, erythrocyte protoporphyrin in treated and untreated normal and anemic patients. Am. J. Obst. \& Gynec., 1951, 62, 947.

26. Benstead, N., and Theobald, G. W., Iron and the "physiological" anaemia of pregnancy. Brit. M. J., 1952, i, 407.

27. Schade, A. L., and Caroline, L., An iron-binding component in human blood plasma. Science, 1946, 104, 340.

28. Plass, E. D., and Matthew, C. W., Plasma protein fractions in normal pregnancy, labor, and puerperium. Am. J. Obst. \& Gynec., 1926, 12, 346.

29. Hoch, H., and Marrack, J. R., The composition of the blood of women during pregnancy and after delivery. J. Obst. \& Gynaec. Brit. Emp., 1948, 55, 1. 